\title{
Recent advances in understanding and treating nephrotic
}

\section{syndrome [version 1; peer review: 2 approved]}

\author{
Agnieszka Bierzynska, Moin Saleem (iD) \\ University of Bristol, Bristol Royal Hospital for Children, Bristol, UK
}

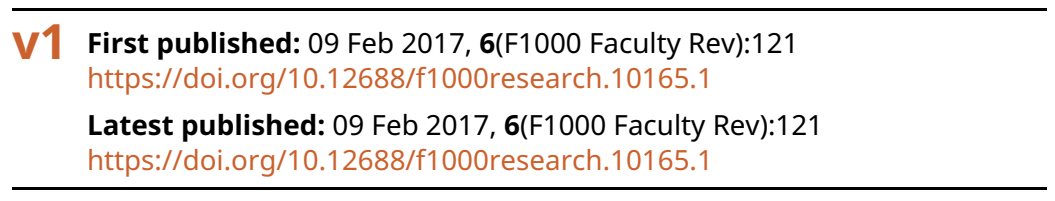

\section{Abstract}

Idiopathic nephrotic syndrome (INS) is one of the most common glomerular diseases in children and adults, and the central event is podocyte injury. INS is a heterogeneous disease, and treatment is largely empirical and in many cases unsuccessful, and steroids are the initial mainstay of therapy. Close to $70 \%$ of children with INS have some response to steroids and are labelled as steroid-'sensitive', and the rest as steroid-'resistant' (also termed focal segmental glomerulosclerosis), and single-gene mutations underlie a large proportion of the latter group. The burden of morbidity is enormous, both to patients with lifelong chronic disease and to health services, particularly in managing dialysis and transplantation. The target cell of nephrotic syndrome is the glomerular podocyte, and podocyte biology research has exploded over the last 15 years. Major advances in genetic and biological understanding now put clinicians and researchers at the threshold of a major reclassification of the disease and testing of targeted therapies both identified and novel. That potential is based on complete genetic analysis, deep clinical phenotyping, and the introduction of mechanism-derived biomarkers into clinical practice. INS can now be split off into those with a singlegene defect, of which currently at least 53 genes are known to be causative, and the others. Of the others, the majority are likely to be immune-mediated and caused by the presence of a still-unknown circulating factor or factors, and whether there is a third (or more) mechanistic group or groups remains to be discovered. Treatment is therefore now being refined towards separating out the monogenic cases to minimise immunosuppression and further understanding how best to stratify and appropriately direct immunosuppressive treatments within the immune group. Therapies directed specifically towards the target cell, the podocyte, are in their infancy but hold considerable promise for the near future.

\section{Keywords}

idiopathic nephrotic syndrome, minimal change nephrotic syndrome, MCNS, focal segmental glomerulosclerosis, FSGS, SRNS

\author{
Open Peer Review \\ Approval Status \\ 1 \\ 2 \\ version 1 \\ 09 Feb 2017 \\ Faculty Reviews are review articles written by the \\ prestigious Members of Faculty Opinions. The \\ articles are commissioned and peer reviewed \\ before publication to ensure that the final, \\ published version is comprehensive and \\ accessible. The reviewers who approved the final \\ version are listed with their names and \\ affiliations. \\ 1. Georges Deschênes, Hôpital universitaire \\ Robert-Debré, Paris, France \\ 2. Arvind Bagga, All India Institute of Medical \\ Sciences, New Delhi, India \\ Any comments on the article can be found at the \\ end of the article.
}


Corresponding author: Moin Saleem (M.Saleem@bristol.ac.uk)

Competing interests: The authors declare that they have no competing interests.

Grant information: The author(s) declared that no grants were involved in supporting this work.

Copyright: @ 2017 Bierzynska A and Saleem M. This is an open access article distributed under the terms of the Creative Commons Attribution License, which permits unrestricted use, distribution, and reproduction in any medium, provided the original work is properly cited.

How to cite this article: Bierzynska A and Saleem M. Recent advances in understanding and treating nephrotic syndrome [version

1; peer review: 2 approved] F1000Research 2017, 6(F1000 Faculty Rev):121 https://doi.org/10.12688/f1000research.10165.1

First published: 09 Feb 2017, 6(F1000 Faculty Rev):121 https://doi.org/10.12688/f1000research.10165.1 


\section{Introduction}

The glomerulus is the filtration unit of the kidney and allows the passage of vast amounts of water and small solutes (180 l per day in an adult human) into the urinary space while preventing the passage of almost any protein $(<30 \mathrm{mg} /$ day $)$. This highly specialised property is achieved by the glomerular filtration barrier (GFB), comprising endothelial cells, a unique basement membrane, and podocytes on the urinary side.

Damage to the GFB can come from many potential sources, including genetic defects (primarily affecting podocytes), paracrine events (for example, affecting endothelial-podocyte cross-talk or from adjacent mesangial cells), or systemic circulating insults. The last of these can take many forms, including circulating immune complexes, metabolic disturbances (most commonly, diabetes), infections, toxins (for example, shiga toxin in haemolytic uraemic syndrome) and drugs.

The clinical manifestation is of oedema, low serum albumin, and massive proteinuria. This leads to numerous consequences, related to circulatory/dynamic effects, and loss of essential circulating proteins.

Idiopathic, or primary, nephrotic syndrome is often used to describe the group of patients for whom no specific cause has been identified, and the histology is relatively non-specific. These patients will usually receive immunosuppression without knowledge of the mechanism and be categorised according to response. So the challenge is to understand and categorise the underlying injury at a molecular level and therefore adapt treatments according to the likely mechanism.

\section{Idiopathic nephrotic syndrome current classification}

Current classification of idiopathic nephrotic syndrome (INS) is based on observational characteristics. This can be according to response to steroids, which is the usual first-line response, or according to light microscopy patterns of injury on renal biopsy. The commonest biopsy finding, particularly in children, is of 'minimal change' nephrotic syndrome (MCNS). This means that light microscopy is entirely normal, importantly not even showing any signs of immune infiltration or upregulation of immune markers. Pathology is seen only at the level of electron microscopy, where effacement or flattening of podocyte foot processes is the characteristic finding in any patient with nephrosis. The next most common biopsy finding (between $10 \%$ and $20 \%$ of patients) is of focal segmental glomerulosclerosis (FSGS), a description of chronic, fibrotic damage in the glomerulus. Response to therapy often (but not always) correlates with these biopsy findings, in that most patients with MCNS will be sensitive to steroids and most with FSGS will be resistant. However, there are many shades in between these phenotypes, and patients frequently become relapsing, steroid-dependent, calcineurin-responsive, and so on. This reflects our lack of knowledge of the underlying mechanisms and the need for a different approach to this disease.

\section{Genetics}

The most concrete advance in establishing the underlying mechanistic cause of INS in recent years has been the discovery that a substantial proportion of patients with steroid-resistant nephrotic syndrome (SRNS) have a single-gene mutation causing their disease (Table 1). To date, at least 53 different genes have been implicated ${ }^{1}$, almost all causing structural or functional defects in the podocyte. Some mutations cause isolated kidney disease, others are part of a syndromic condition. Most are autosomal-recessive, though a few present as X-linked or autosomal-dominant, the latter usually presenting later in life. Some genes have been linked with steroid or cyclosporine sensitivity, such as $E M P 2^{2}$ or $K A N K$ genes $^{3}$, though the data are still sporadic and need consistent verification in other pedigrees.

The incidence of genetic disease in the population varies with age, and over $80 \%$ of patients presenting under the age of a year have an identifiable mutation ${ }^{4,5}$. Overall, in childhood, the incidence in an unselected UK national cohort of SRNS has been reported as $26.5 \%^{1}$. The incidence in adulthood remains to be ascertained, and phenotype even within individual pedigrees, such as ACTN4 mutations $^{6}$, is often highly variable.

With the advent of next-generation sequencing, the ability to screen for genetic causes in a clinical setting, despite the everincreasing number of genes to be screened, has become practical, cost-effective and rapid $^{7}$ and is changing clinical practice. Gene panels such as the Bristol SRNS panel (https://www.nbt.nhs.uk/ severn-pathology/pathology-services/bristol-genetics-laboratory-bgl) can now yield a result within 4 weeks, thus potentially obviating the need for a biopsy and allowing consideration of early withdrawal of immunosuppression if a positive result is found.

\section{Circulating factor disease}

Patients who screen negative for the known SRNS genes, as well as those with steroid-sensitive disease, fall into a category wherein a substantial proportion will have an immune-mediated, circulating factor disease (CFD). The evidence for this remains circumstantial, and the most compelling clinical scenario is that of post-transplant recurrence of disease $\mathrm{e}^{8}$. This is a situation where patients with SRNS who eventually reach established renal failure are then transplanted. Between $30 \%$ and $50 \%$ of patients suffer from rapid (most commonly, hours or days post-transplant) recurrence of massive proteinuria, and biopsy of the new kidney shows classic foot process effacement. This is presumed to be due to a circulating factor, and a fascinating recent case report described a patient with early recurrence, whose newly transplanted kidney was then removed and re-transplanted into a recipient without SRNS, and the kidney recovered completely ${ }^{9}$. It is not known where the circulating factor or factors originate, but the fact that immunosuppression is often effective, and relapses are often triggered by viral infections, points to the immune system (Table 2). Both $\mathrm{T}$ cells and $\mathrm{B}$ cells have been implicated ${ }^{10}$; for 
Table 1. Some of the more common genes mutated in monogenic steroid-'resistant' nephrotic syndrome.

\begin{tabular}{|c|c|c|c|c|c|}
\hline Function & Protein & Gene & Syndrome & $\begin{array}{l}\text { Mode of } \\
\text { inheritance }\end{array}$ & Histology \\
\hline \multirow[t]{7}{*}{$\begin{array}{l}\text { Slit diaphragm } \\
\text { protein }\end{array}$} & Nephrin & NPHS1 & $\begin{array}{l}\text { Congenital nephrotic } \\
\text { syndrome }\end{array}$ & $A R$ & $\begin{array}{l}\text { Microcystic dilatation of } \\
\text { tubules and progressive } \\
\text { mesangial sclerosis }\end{array}$ \\
\hline & & & SRNS & AR & MPGN, MCD, FSGS \\
\hline & Podocin & NPHS2 & $\begin{array}{l}\text { Congenital nephrotic } \\
\text { syndrome }\end{array}$ & AR & \\
\hline & & & SRNS & AR & FSGS \\
\hline & PLCE1 & NPHS3 & DMS & AR & DMS \\
\hline & & & SRNS & AR & FSGS \\
\hline & CD2AP & CD2AP & SRNS & AD/AR & FSGS \\
\hline SD ion channel & TRPC6 & TRPC6 & SRNS & $A D$ & FSGS \\
\hline \multirow[t]{3}{*}{ Developmental } & WT1 & WT1 & $\begin{array}{l}\text { Denys-Drash } \\
\text { syndrome }\end{array}$ & $A D$ & DMS \\
\hline & & & Frasier syndrome & $A D$ & FSGS \\
\hline & & & Isolated SRNS & $A R$ & DMS, FSGS \\
\hline \multirow[t]{2}{*}{ Actin regulating } & $\alpha$-Actinin 4 & ACTN4 & Adult-onset SRNS & $A D$ & FSGS \\
\hline & Inverted formin 2 & INF2 & SRNS & $A D$ & FSGS \\
\hline $\begin{array}{l}\text { Glomerular basement } \\
\text { membrane }\end{array}$ & Laminin $\beta 2$ & LAMB2 & Pierson syndrome & AR & DMS, FSGS \\
\hline \multirow[t]{10}{*}{ Others } & tRNA-LEU & MTTL1 & MELAS & Maternal & FSGS \\
\hline & $\begin{array}{l}\text { Parahydroxybenzoate- } \\
\text { polyprenyltransferase }\end{array}$ & COQ2 & CoQ10 deficiency & AR & $\begin{array}{l}\text { Collapsing } \\
\text { glomerulopathy }\end{array}$ \\
\hline & $\begin{array}{l}\text { Prenyl diphosphate } \\
\text { synthase subunit } 2\end{array}$ & PDSS2 & $\begin{array}{l}\text { CoQ10 deficiency/ } \\
\text { Leigh syndrome }\end{array}$ & $A R$ & FSGS \\
\hline & SMARCA-like protein & SMARCL1 & $\begin{array}{l}\text { Schimke immuno- } \\
\text { osseous dysplasia }\end{array}$ & $\mathrm{AR}$ & FSGS \\
\hline & $\begin{array}{l}\text { Lysosomal integral } \\
\text { membrane protein type } 2\end{array}$ & SCARB2 & $\begin{array}{l}\text { Action myoclonus- } \\
\text { renal failure } \\
\text { syndrome }\end{array}$ & $\mathrm{AR}$ & \\
\hline & $\begin{array}{l}\text { LIM homeobox } \\
\text { transcription factor } 1 \beta\end{array}$ & $L M X 1 B$ & $\begin{array}{l}\text { Nail patella } \\
\text { syndrome }\end{array}$ & $A D$ & FSGS \\
\hline & $\begin{array}{l}\text { Zinc metallo-proteinase } \\
\text { STE24 }\end{array}$ & ZMPSTE24 & $\begin{array}{l}\text { Mandibuloacral } \\
\text { dysplasia }\end{array}$ & $\mathrm{AR}$ & \\
\hline & $\begin{array}{l}\text { WD repeat-containing } \\
\text { protein } 73\end{array}$ & WDR73 & $\begin{array}{l}\text { Galloway-Mowat } \\
\text { syndrome }\end{array}$ & $A R$ & DMS, FSGS \\
\hline & Phosphomannomutase 2 & PMM2 & $\begin{array}{l}\text { Congenital defects } \\
\text { of glycosylation }\end{array}$ & $A R$ & $\begin{array}{l}\text { Collapsing } \\
\text { glomerulopathy }\end{array}$ \\
\hline & $\beta$-1, 4-Mannosyltransferase & ALG1 & $\begin{array}{l}\text { Congenital defects } \\
\text { of glycosylation }\end{array}$ & AR & FSGS \\
\hline
\end{tabular}

AD, autosomal-dominant; AR, autosomal-recessive; CoQ10, coenzyme $Q_{1}$; DMS, diffuse mesangial sclerosis; FSGS, focal segmental glomerulosclerosis; MCD, minimal change disease; MELAS, mitochondrial myopathy, encephalopathy, lactic acidosis and stroke-like episodes; MPGN, membranoproliferative glomerulonephritis; SRNS, steroid-'resistant' nephrotic syndrome. 
Table 2. A selection of suggested circulating factors in idiopathic nephrotic syndrome.

\begin{tabular}{|c|c|}
\hline Postulated circulating factor & Experimental or clinical evidence \\
\hline Hemopexin & $\begin{array}{l}\text { Both recombinant and human hemopexin induced reversible proteinuria in rats }{ }^{32} \text {. Decreased } \\
\text { serum hemopexin with increased protease activity in 'minimal change' nephrotic syndrome } \\
\text { (MCNS) in relapse }{ }^{33} \text {. Induced nephrin-dependent cytoskeletal rearrangements in podocytes }\end{array}$ \\
\hline $\begin{array}{l}\text { SUPAR } \\
\text { (soluble urokinase-type } \\
\text { plasminogen activator receptor) }\end{array}$ & $\begin{array}{l}\text { Activated podocyte } \beta 3 \text { integrin, resulting in reorganisation of the actin cytoskeleton } \\
\text { High levels were reported in patients with focal segmental glomerulosclerosis (FSGS) and } \\
\text { post-transplant recurrence }{ }^{35} \text {. Clinical data were not consistently replicated in other studies }{ }^{36} \text {. }\end{array}$ \\
\hline $\begin{array}{l}\text { Tumour necrosis factor-alpha } \\
(\text { TNF } \alpha)\end{array}$ & $\begin{array}{l}\text { Increased concentrations were found in culture supernatants of mitogen-stimulated peripheral } \\
\text { blood mononuclear cells from patients with FSGS } \\
\text { Four of ten children with primary FSGS exhibited remission of proteinuria in a phase I trial of a } \\
\text { TNF } \alpha \text {-neutralising antibody }{ }^{38} \text {. }\end{array}$ \\
\hline Interleukin-13 (IL-13) & $\begin{array}{l}\text { Increased expression of mRNA and cytoplasmic IL-13 in } \mathrm{CD} 4^{+} / \mathrm{CD} 8^{+} \mathrm{T} \text { cells from children with } \\
\text { steroid-sensitive idiopathic nephrotic syndrome }{ }^{39} \text {. Overexpression of IL-13 in rats induces } \\
\text { MCNS-like disease }{ }^{40} \text {. }\end{array}$ \\
\hline $\begin{array}{l}\text { Galactose (inhibitor of } \\
\text { circulating factor) }\end{array}$ & $\begin{array}{l}\text { Binds to putative circulating factor and inhibits its activity }{ }^{41} \text {. A clinical trial of galactose showed } \\
\text { no remission effect }{ }^{42} \text {. }\end{array}$ \\
\hline
\end{tabular}

example, anti-CD20 B cell-depleting monoclonal antibodies are highly effective in some patients ${ }^{11}$, and a $\mathrm{T}$ helper 17/regulatory $\mathrm{T}$ (Th17/Treg) cell imbalance has been described in minimal change disease ${ }^{12}$. Another clue to a circulating factor pathogenesis in steroid-sensitive nephrotic syndrome, where the biopsy shows minimal change, is the lack of immune cell infiltration or activation within the glomerulus itself.

A significant gap in our knowledge is whether there is one common circulating factor that causes all forms of the disease, or several distinct factors, or possibly a family of related factors. There are no indications at present, either laboratory or clinical, that help to resolve this question, though we have made progress in some areas of prediction of CFD.

\section{Clinical biomarkers}

There have been no consistent clinical cues to either whether a patient with nephrotic syndrome has the risk of becoming steroidresistant in the future or whether they will suffer recurrence posttransplant. There are weak clinical associations with recurrence (for example, age at onset of disease ${ }^{13,14}$, race $^{15}$, serum albumin at diagnosis $^{13}$ or time to first dialysis/transplant ${ }^{13,15,16}$ ). Interestingly, the last two features may point to the possibility that CFD has a more aggressive presentation and natural course, compared with the monogenic or 'other' groups. To address the question of whether there are clinical features that pertain to CFD, we hypothesised that patients with the archetypal CFD, those with post-transplant recurrence, would have distinct early clinical features regarding their initial response to immunosuppression. If a patient has initial steroid sensitivity (otherwise described as secondary steroid resistance), they are likely to have an immune-mediated circulating factor causing their underlying disease and therefore high risk of recurrence. On retrospective review of 150 transplanted patients with SRNS, we found that $93 \%$ of patients with initial steroid sensitivity recurred post-transplant (odds ratio $=30$, $P<0.0001$ ), making this by far the strongest clinical biomarker for recurrent disease yet found ${ }^{17}$.

\section{Laboratory biomarkers}

Over many decades, researchers have searched for the elusive circulating factor or factors, but there has been no consistent answer to date ${ }^{18}$. Clearly, if the factor were identified, this would be the ideal biomarker to both diagnose and monitor disease activity. There are other rational ways to approach biomarker discovery, based on the fact that circulating blood from patients with active disease is likely to carry the active factor and that we know the most likely target cell of such a factor, the podocyte. Therefore, an approach of stimulating human podocytes in vitro with plasma or serum from disease has been used by ourselves and others, and podocyte damage has been assayed in various ways. For example, we have shown that plasma exchange fluid from patients being treated for post-transplant recurrence causes relocalisation of key podocyte slit diaphragm proteins ${ }^{19}$ and abnormal signalling and cell motility ${ }^{20}$. Torban et al. showed a tumour necrosis factor-alpha $(\mathrm{TNF} \alpha)$ pathway-dependent change in podocyte cytoskeletal changes ${ }^{21}$ and also changes in podocyte focal adhesion complexes ${ }^{22}$. The challenge is to show consistency and disease specificity by using these types of assays, before they can be introduced into clinical practice.

\section{Newer therapies}

The mainstay of current therapy is immunosuppression, which is appropriate for the immune-mediated group of diseases, but there is very limited evidence of efficacy in monogenic disease. There are studies that support a direct effect of some immunosuppressive drugs on the podocyte ${ }^{23-27}$, though the majority of clinical evidence points to efficacy being achieved via effects on the immune system. 
Some newer therapies have been proposed on the basis of direct targeting of either the immune system or podocyte signalling pathways. The most prominent of these are the use of anti-CD20 monoclonal antibodies ${ }^{28}$, which deplete B cells, and anti-B7-1 monoclonal antibody therapy ${ }^{29}$. The latter has been proposed following the observation that in certain experimental and human glomerular diseases the T-cell co-stimulatory molecule B7-1 has been noted to be upregulated on podocytes ${ }^{30}$. This can be targeted by the drug abatacept and is the subject of current trials in larger numbers of patients.

\section{Future stratification and personalised medicine}

Our understanding of INS at the molecular, cell biology and genetic levels is advancing rapidly, and the information gained will be critical in stratification and re-categorisation of patients into clinically useful mechanistic categories. The advent of rapid second- and now third-generation sequencing technologies is already changing clinical practice. Exome/genome sequencing, side by side with powerful population sequencing databases such as the exome aggregation consortium (ExAC) ${ }^{31}$, means that novel genes will continue to be discovered, even from sporadic cases, to complete our knowledge of the extent of heritable disease in this population.

A challenge of CFD is to discover whether this is a single entity, or separate mechanistic diseases, and target the most appropriate therapies to the individual groups. For example, is relapsing non-progressive disease different from secondary steroid resistance, which usually leads to renal failure (and recurrence posttransplant)?

Novel therapies based on common podocyte signalling pathways are already on the horizon, and the availability of large national patient registries currently being developed will greatly accelerate the ability to trial these in appropriately chosen patient groups.

\section{Competing interests}

The authors declare that they have no competing interests.

Grant information

The author(s) declared that no grants were involved in supporting this work.
1. Bierzynska A, McCarthy HJ, Soderquest K, et al.: Genomic and clinical profiling of a national Nephrotic Syndrome cohort advocates a precision medicine approach to disease management. Kidney Int. 2017; pii: S0085-2538(16)30612-3, in press. in press.

2. $\mathrm{F}$ Gee HY, Ashraf S, Wan X, et al:: Mutations in EMP2 cause childhood-onset nephrotic syndrome. Am J Hum Genet. 2014; 94(6): 884-90. PubMed Abstract | Publisher Full Text | Free Full Text | F1000 Recommendation

3. F Gee HY, Zhang F, Ashraf S, et al.: KANK deficiency leads to podocyte dysfunction and nephrotic syndrome. J Clin Invest. 2015; 125(6): 2375-84. PubMed Abstract | Publisher Full Text | Free Full Text | F1000 Recommendation

4. Hinkes BG, Mucha B, Vlangos CN, et al:: Nephrotic syndrome in the first year of life: two thirds of cases are caused by mutations in 4 genes (NPHS1, NPHS2, WT1, and LAMB2). Pediatrics. 2007; 119(4): e907-19.

PubMed Abstract | Publisher Full Text

5. F Sadowski CE, Lovric S, Ashraf S, et al:: A single-gene cause in $29.5 \%$ of cases of steroid-resistant nephrotic syndrome. J Am Soc Nephrol. 2015; 26(6): 1279-89.

PubMed Abstract | Publisher Full Text | Free Full Text | F1000 Recommendation

6. $\quad \mathrm{F}$ Kaplan JM, Kim SH, North KN, et al:: Mutations in ACTN4, encoding $\alpha$-actinin-4, cause familial focal segmental glomerulosclerosis. Nat Genet. 2000; 24(3): 251-6

PubMed Abstract | Publisher Full Text | F1000 Recommendation

7. McCarthy HJ, Bierzynska A, Wherlock M, et al:: Simultaneous sequencing of $\mathbf{2 4}$ genes associated with steroid-resistant nephrotic syndrome. Clin J Am Soc Nephrol. 2013; 8(4): 637-48.

PubMed Abstract | Publisher Full Text | Free Full Text

8. Ulinski T: Recurrence of focal segmental glomerulosclerosis after kidney transplantation: strategies and outcome. Curr Opin Organ Transplant. 2010; 15(5): 628-32.

PubMed Abstract | Publisher Full Text

9. $\quad \mathrm{F}$ Gallon L, Leventhal J, Skaro A, et al:: Resolution of recurrent focal segmental glomerulosclerosis after retransplantation. N Engl J Med. 2012; 366(17): 1648-9. PubMed Abstract | Publisher Full Text | F1000 Recommendation

10. van den Berg JG, Weening JJ: Role of the immune system in the pathogenesis of idiopathic nephrotic syndrome. Clin Sci (Lond). 2004; 107(2): 125-36. PubMed Abstract | Publisher Full Text
11. Sinha A, Bagga A: Rituximab therapy in nephrotic syndrome: implications for patients' management. Nat Rev Nephrol. 2013; 9(3): 154-69. PubMed Abstract | Publisher Full Text

12. $\mathrm{F}$ Liu LL, Qin Y, Cai JF, et al.: Th17/Treg imbalance in adult patients with minimal change nephrotic syndrome. Clin Immunol. 2011; 139(3): 314-20. PubMed Abstract | Publisher Full Text | F1000 Recommendation

13. F Maas RJ, Deegens JK, Wetzels JF: Permeability factors in idiopathic nephrotic syndrome: historical perspectives and lessons for the future. Nephrol Dial Transplant. 2014; 29(12): 2207-16.

PubMed Abstract | Publisher Full Text | F1000 Recommendation

14. Pinto J, Lacerda G, Cameron JS, et al:: Recurrence of focal segmental glomerulosclerosis in renal allografts. Transplantation. 1981; 32(2): 83-9. PubMed Abstract | Publisher Full Text

15. Artero M, Biava C, Amend W, et al:: Recurrent focal glomerulosclerosis: natural history and response to therapy. Am J Med. 1992; 92(4): 375-83. PubMed Abstract | Publisher Full Text

16. Sener A, Bella AJ, Nguan C, et al:: Focal segmental glomerular sclerosis in renal transplant recipients: predicting early disease recurrence may prolong allograft function. Clin Transplant. 2009; 23(1): 96-100. PubMed Abstract | Publisher Full Text

17. Ding WY, Koziell A, McCarthy HJ, et al.: Initial steroid sensitivity in children with steroid-resistant nephrotic syndrome predicts post-transplant recurrence. J Am Soc Nephrol. 2014; 25(6): 1342-8. PubMed Abstract | Publisher Full Text | Free Full Text

18. $F$ Konigshausen E, Sellin L: Circulating Permeability Factors in Primary Focal Segmental Glomerulosclerosis: A Review of Proposed Candidates. Biomed Res Int. 2016; 2016: 3765608.

PubMed Abstract | Publisher Full Text | Free Full Text | F1000 Recommendation

19. Coward RJ, Foster RR, Patton D, et al.: Nephrotic plasma alters slit diaphragmdependent signaling and translocates nephrin, Podocin, and CD2 associated protein in cultured human podocytes. J Am Soc Nephrol. 2005; 16(3): 629-37. PubMed Abstract | Publisher Full Text

20. Harris $\mathrm{JJ}$, McCarthy HJ, Ni L, et al.: Active proteases in nephrotic plasma lead to a podocin-dependent phosphorylation of VASP in podocytes via protease activated receptor-1. J Pathol. 2013; 229(5): 660-71.

PubMed Abstract | Publisher Full Text

21. Bitzan M, Babayeva S, Vasudevan A, et al.: TNF $\alpha$ pathway blockade ameliorates 
toxic effects of FSGS plasma on podocyte cytoskeleton and $\mathbf{\beta 3}$ integrin activation. Pediatr Nephrol. 2012; 27(12): 2217-26.

PubMed Abstract | Publisher Full Text

22. F Kachurina N, Chung CF, Benderoff E, et al:: Novel unbiased assay for circulating podocyte-toxic factors associated with recurrent focal segmental glomerulosclerosis. Am J Physiol Renal Physiol. 2016; 310(10): F1148-56. PubMed Abstract | Publisher Full Text | F1000 Recommendation

23. F Faul C, Donnelly M, Merscher-Gomez S, et al:: The actin cytoskeleton of kidney podocytes is a direct target of the antiproteinuric effect of cyclosporine A. Nat Med. 2008; 14(9): 931-8.

PubMed Abstract | Publisher Full Text | Free Full Text | F1000 Recommendation

24. F Jiang L, Dasgupta I, Hurcombe JA, et al.: Levamisole in steroid-sensitive nephrotic syndrome: usefulness in adult patients and laboratory insights into mechanisms of action via direct action on the kidney podocyte. Clin Sci (Lond). 2015; 128(12): 883-93.

PubMed Abstract | Publisher Full Text | F1000 Recommendation

25. Mathieson PW: Immunomodulatory Drugs and the Podocyte. Podocytopathy 2014; 183: 199-206. Reference Source

26. Xing CY, Saleem MA, Coward RJ, et al.: Direct effects of dexamethasone on human podocytes. Kidney Int. 2006; 70(6): 1038-45. PubMed Abstract | Publisher Full Text

27. F Fornoni A, Sageshima J, Wei C, et al.: Rituximab targets podocytes in recurrent focal segmental glomerulosclerosis. Sci Transl Med. 2011; 3(85): 85 ra46.

PubMed Abstract | Publisher Full Text | Free Full Text | F1000 Recommendation

28. Ravani P, Ponticelli A, Siciliano C, et al.: Rituximab is a safe and effective longterm treatment for children with steroid and calcineurin inhibitor-dependent idiopathic nephrotic syndrome. Kidney Int. 2013; 84(5): 1025-33. PubMed Abstract | Publisher Full Text | Free Full Text

29. F Yu CC, Fornoni A, Weins A, et al:: Abatacept in B7-1-positive proteinuric kidney disease. N Engl J Med. 2013; 369(25): 2416-23. PubMed Abstract | Publisher Full Text | Free Full Text | F1000 Recommendation

30. F Mundel P, Greka A: Developing therapeutic 'arrows' with the precision of William Tell: the time has come for targeted therapies in kidney disease. Curr Opin Nephrol Hypertens. 2015; 24(4): 388-92. PubMed Abstract | Publisher Full Text | Free Full Text | F1000 Recommendation

31. F Lek M, Karczewski KJ, Minikel EV, et al:: Analysis of protein-coding genetic variation in 60,706 humans. Nature. 2016; 536(7616): 285-91.

PubMed Abstract | Publisher Full Text | Free Full Text | F1000 Recommendation
32. Cheung PK, Klok PA, Baller JF, et al.: Induction of experimental proteinuria in vivo following infusion of human plasma hemopexin. Kidney Int. 2000; 57(4) 1512-20.

PubMed Abstract | Publisher Full Text

33. Bakker WW, van Dael CM, Pierik LJ, et al:: Altered activity of plasma hemopexin in patients with minimal change disease in relapse. Pediatr Nephrol. 2005; 20(10): 1410-5.

PubMed Abstract | Publisher Full Text

34. F Lennon R, Singh A, Welsh Gl, et al:: Hemopexin induces nephrin-dependent reorganization of the actin cytoskeleton in podocytes. J Am Soc Nephrol. 2008; 19(11): 2140-9.

PubMed Abstract | Publisher Full Text | Free Full Text | F1000 Recommendation

35. $\mathrm{F}$ Wei $\mathrm{C}$, El Hindi S, Li J, et al.: Circulating urokinase receptor as a cause of focal segmental glomerulosclerosis. Nat Med. 2011; 17(8): 952-60.

PubMed Abstract | Publisher Full Text | Free Full Text | F1000 Recommendation

36. Kronbichler A, Saleem MA, Meijers B, et al:: Soluble Urokinase Receptors in Focal Segmental Glomerulosclerosis: A Review on the Scientific Point of View. $J$ Immunol Res. 2016; 2016: 2068691. PubMed Abstract | Publisher Full Text | Free Full Text

37. $\mathrm{F}$ Bakr A, Shokeir M, El-Chenawi $\mathrm{F}$, et al:: Tumor necrosis factor-alpha production from mononuclear cells in nephrotic syndrome. Pediatr Nephrol. 2003; 18(6): 516-20 PubMed Abstract | F1000 Recommendation

38. Joy MS, Gipson DS, Powell L, et al: Phase 1 trial of adalimumab in Focal Segmental Glomerulosclerosis (FSGS): II. Report of the FONT (Novel Therapies for Resistant FSGS) study group. Am J Kidney Dis. 2010; 55(1): 50-60. PubMed Abstract | Publisher Full Text | Free Full Text

39. Kim SH, Park SJ, Han KH, et al.: Pathogenesis of minimal change nephrotic syndrome: an immunological concept. Korean J Pediatr. 2016; 59(9): 205-11. PubMed Abstract | Publisher Full Text | Free Full Text

40. F Lai KW, Wei CL, Tan LK, et al.: Overexpression of interleukin-13 induces minimal-change-like nephropathy in rats. J Am Soc Nephrol. 2007; 18(5): 1476-85. PubMed Abstract | Publisher Full Text | F1000 Recommendation

41. Savin VJ, McCarthy ET, Sharma R, et al:: Galactose binds to focal segmenta glomerulosclerosis permeability factor and inhibits its activity. Transl Res. 2008; 151(6): 288-92.

PubMed Abstract | Publisher Full Text

42. Sgambat K, Banks M, Moudgil A: Effect of galactose on glomerular permeability and proteinuria in steroid-resistant nephrotic syndrome. Pediatr Nephrol. 2013; 28(11): 2131-5.

PubMed Abstract | Publisher Full Text 


\section{Open Peer Review}

\section{Current Peer Review Status:}

\section{Editorial Note on the Review Process}

Faculty Reviews are review articles written by the prestigious Members of Faculty Opinions. The articles are commissioned and peer reviewed before publication to ensure that the final, published version is comprehensive and accessible. The reviewers who approved the final version are listed with their names and affiliations.

\section{The reviewers who approved this article are:}

\section{Version 1}

\section{Arvind Bagga}

Division of Pediatric Nephrology, All India Institute of Medical Sciences, New Delhi, India

Competing Interests: No competing interests were disclosed.

\section{Georges Deschênes}

Hôpital universitaire Robert-Debré, Paris, France

Competing Interests: No competing interests were disclosed.

The benefits of publishing with F1000Research:

- Your article is published within days, with no editorial bias

- You can publish traditional articles, null/negative results, case reports, data notes and more

- The peer review process is transparent and collaborative

- Your article is indexed in PubMed after passing peer review

- Dedicated customer support at every stage

For pre-submission enquiries, contact research@f1000.com 